\title{
Forms of Address and Epistolary Etiquette in the Diplomatic and Courtly Worlds of Philip IV of Spain
}

Lynn Williams

lynn_williams@byu.edu

Follow this and additional works at: https://scholarsarchive.byu.edu/facpub

Part of the Spanish and Portuguese Language and Literature Commons

\section{Original Publication Citation}

Williams, L. "Forms of Address and Epistolary Etiquette in the Diplomatic and Courtly Worlds of Philip IV of Spain", The Bulletin of Spanish Studies, LXXXI, No 1 (24), pp. 15-36.

\section{BYU ScholarsArchive Citation}

Williams, Lynn, "Forms of Address and Epistolary Etiquette in the Diplomatic and Courtly Worlds of Philip IV of Spain" (2004). Faculty Publications. 1029.

https://scholarsarchive.byu.edu/facpub/1029 


\title{
Forms of Address and Epistolary Etiquette in the Diplomatic and Courtly Worlds of Philip IV of Spain
}

\author{
LYNN WILLIAMS \\ Brigham Young University, Provo, Utah
}

\section{Introduction}

Observance of established etiquette in the matter of forms of address is a feature of all societies in all ages. Nowhere could this be more evident than in the diplomatic and courtly worlds of Philip IV of Spain. The following extract from the entry on 'tratamiento' in the Enciclopedia Universal Ilustrada will serve to set the scene for this period in Spanish history:

Contra las infracciones de las reglas sobre el tratamiento se dictó ya el 2 de Julio de 1600 por Felipe III una Pragmática y otra en 1636 por Felipe IV disponiendo «que los que vinieren contra lo dispuesto y ordenado, así hombres como mujeres, caigan é incurran cada uno de ellos por la primera vez en pena de doscientos ducados, por la segunda en cuatrocientos ducados y por la tercera en mil ducados y un año de destierro de la corte á cinco leguas, y de las ciudades, villas y lugares del Reino y jurisdicción donde se quebrantare la ley; cuyas penas pague así el que diere la cortesía como el que la recibiere enteramente, y el tercero que lo oyere, si no avisare al que lo pueda remediar; y que los testigos en estos casos pudiesen declarar en secreto, y el denunciador también". ${ }^{1}$

The language of these pragmatic sanctions is clear and direct. It suggests a society that is highly stratified and, more importantly, resolved to preserve the requisite distance between its members by imposing heavy penalties not merely on the giver and receiver of inappropriate forms of address, but also on any who might idly look on while such violations of the law occurred. The trial procedures governing the treatment of witnesses and accusers are redolent, in their secrecy, of those employed by the Inquisition,

1 Enciclopedia Universal Ilustrada, 70 vols (Madrid: Espasa Calpe, 1928), LXIII, 1537.

ISSN 1475-3820 print/ISSN 1478-3428 online/04/010015-22

(C) Bulletin of Spanish Studies. DOI: $10.1080 / 145382032000184291$ 
while the penalty reserved for the recalcitrant offender, if imposed, may be described as draconian. Banishment from court and the royal presence was a serious measure. Monarchs resorted to it for a variety of reasons, including, on occasion, the punishment of ambassadors deemed not to have discharged properly their duties abroad. ${ }^{2}$ Its impact on the individual concerned would have been profound. At the very least, exclusion from court and/or from the town or city where the violation occurred may be assumed seriously to have affected the psychological well-being of the accused and damaged his reputation. Additionally, the thousand ducats constituting the fine to be paid represent a considerable sum of money. Using the standard set of equivalences, we can form some idea of its magnitude. ${ }^{3}$ A thousand ducats are equal to 11,000 reales de plata. During the 1620 s and $1630 \mathrm{~s}$, a Spanish embassy secretary typically earned 30 escudos de a doce reales or 360 reales de plata per month. ${ }^{4}$ The fine imposed for repeated infractions of the law governing forms of address thus comes to approximately two and a half years' salary of an embassy secretary.

Such strict regulation of the way in which individuals address each other implies an obsession that is difficult for speakers of modern English to comprehend. However, this obsession was by no means uniquely Spanish in the seventeenth century. As we shall see, it was widespread in Europe, especially at the highest levels of society. Consequently, diplomatic exchanges between European governments or with prominent nobles needed to be conducted with the utmost sensitivity.

\section{Bipolar Versus Multi-polar Systems of Address}

Several decades ago, Brown and Gilman published an excellent study of the use in several languages of second person singular forms of address. ${ }^{5}$ Their

2 In October 1661, the Spanish and French ambassadors to Charles II clashed violently on the streets of restoration London over a matter of precedence relating to the formal entry of the Swedish ambassador extraordinary into the city. Following their return to their respective countries, both ambassadors were denied, for a time, access to court and the royal presence. In this, Philip IV and Louis XIV may be seen to have acted in perfect unison. See Count of Fuensaldaña to Philip IV, La Chapelle, 28 October 1661, Archivo General de Simancas (A.G.S.), Estado Flandes 2098; Gabriel Díaz de la Questa to Court in Madrid, Laredo, 14 September 1662, A.G.S., Estado 2532.

3 The standard equivalences of silver coinage are as follows: 1 ducado $=11$ reales $=$ 374 maravedíes; 1 escudo $=10$ reales $=340$ maravedies; 1 real $=34$ maravedíes. However, there were also escudo coins with values other than 10 reales de plata, as well as reales de $a$ dos, de a cuatro, de a ocho, de a cincuenta.

4 Report of the Council of State, Madrid, 25 February 1634, A.G.S., Estado Francia K1417: 11. This is the amount that the Marquis of Mirabel paid his secretary during his embassy in Paris, which lasted from 20 September 1620 to the end of 1631 . It seems to have been a standard sum. Foreign language secretaries (secretarios de lenguas) earned exactly half, i.e. 180 reales de plata.

5 R. Brown and A. Gilman, 'The Pronouns of Power and Solidarity', in Language and 
main focus in this study is the historical development of a bipolar pronominal system in which $\mathrm{T}$ represents familiarity and $\mathrm{V}$ politeness. Under this system, reciprocal pronominal usage traditionally expressed a sense of equality or solidarity between speakers while nonreciprocal usage reflected the power one speaker had over another. According to these authors, this traditional system has undergone dramatic transformation in the modern era. Since the French Revolution, solidarity has triumphed over power and, coincidentally, reciprocal over nonreciprocal pronominal forms of address.

In broad terms, Brown and Gilman are undoubtedly correct in their assessment of the dynamics underlying second person singular forms of address and the manner in which the system has evolved in recent history. However, the system, at least in so far as the highest levels of seventeenthcentury European society are concerned, is hardly bipolar. Rather it consists of a series of subtle gradations that mirror the complexities of a highly stratified world in which everyone and everything have their proper place. Thus it is that we find in Spanish documents of the period not only 'vos' and 'Vuestra Merced', but also a host of other forms that include 'Vuestra Ilustrísima', 'Vuestra Señoría', 'Vuestra Excelencia', 'Vuestra Eminencia', Vuestra Alteza', 'Vuestra Majestad' and 'Vuestra Santidad/Beatitud'. We find too forms like 'hermano', 'primo', 'sobrino', 'pariente' and 'amigo' used by the Spanish monarch in order to signal the status of the person addressed and the regard in which he or she is held. ${ }^{6}$ Brown and Gilman note that 'where status is fixed by birth and does not change each man has enduring rights and obligations of address'. ${ }^{7}$ This explains why in a seventeenth-century context, addressees, whether of inferior status or not, expected to be accorded forms of address consonant with their ranking in society and, moreover, were ever alert to how others of similar standing and importance to themselves were addressed by the same interlocutor. Such preoccupations extended to the precise format of written correspondence and even to the language in which the correspondence was framed.

The complexity of the rules governing forms of address at this time, coupled with the determination of individuals not to be accorded less respect than was their due, led to frequent misunderstandings and disagreements. Unusual or unprecedented situations generally caused bewilderment among those involved and thus the need to consult officials whose duty it was to advise on such matters, while those of diplomatic consequence were debated in the Council of State. The following are typical

Social Context, ed. Pier Paolo Giglioli (Harmondsworth:-Penguin Books, 1972; repr. 1975), 252-82.

6 See appendix for explanation of the use of these and other forms as recorded in Covarrubias' Tesoro of 1611 and in Autoridades.

7 Brown and Gilman, 'The Pronouns of Power and Solidarity', 271. 
of the kinds of situation encountered in the reign of Philip IV.

\section{The Diplomatic World of Philip IV}

Charles II of England: in 1656, Philip struck a treaty with Charles, the English king in exile during the Commonwealth of 1649-1660. This treaty included a promise of Spanish assistance to recover the English throne in exchange for the services of Charles' English and Irish troops against France and help against Portugal after the English king's restoration. Under its terms, Charles received an irregularly paid pension and he and his brother, the Duke of York, were allowed to reside in the Low Countries following their exclusion from France. However, long before Charles' arrival in the Low Countries, Archduke Leopold had written to Madrid in his capacity as Governor General of Flanders, expressing concern over how to address a king without a kingdom. In this letter, Leopold noted that he had had no difficulty addressing Charles as an equal when the latter was simply Prince of Wales, but now he was unsure of Charles' precise status. With an eye on reactions elsewhere in Europe, he reported the following:

No he querido ser el primero que resoluiese el tratamiento deste Principe, tan contra razon, y drecho [sic] despojado de sus reynos, y estados hauiendo entendido que Holandeses, hauian embiado sus Diputados a condolerse con este Principe a quien llamaron sire en lengua francesa, y vna vez (mal pronunciada) le trataron de Majestad sin hauer querido dar por escrito lo que dijeron de palabra. ${ }^{8}$

The archduke's letter was considered by the Council of State on 29 March. The four members of the council present on that occasion were keenly aware that all Europe was waiting to see the manner in which princes in rival European courts would address Charles. Consequently, they came up with a cautious, yet ingenious recommendation to the king: Leopold should address Charles as 'Majestad' with all his titles. However, his letter to Charles should be backdated so that it might seem to have been written before news of Charles' exclusion from succession to the English throne reached Brussels. In this way, Spain might satisfy Charles without giving offence to the English parliament. ${ }^{9}$

James, Duke of York: on 2 February 1661, secretary D. Gregorio de Tapia wrote a note to the king in connection with a letter from the Baron de

8 Archduke Leopold to Philip IV, Brussels, 4 March 1649, A.G.S., Estado 8341,Vol. 271 , fols $164 \mathrm{r}-164 \mathrm{v}$.

9 Report of the Council of State, Madrid, 29 March 1649, A.G.S., Estado 8341, Vol. 271 , fol. $176 \mathrm{r}$. It is worth noting that Philip had already written to Charles on 10 February 1649 in order to offer the 'new king' his condolences on the death of the latter's father. The document, drafted in Spanish and translated into Latin, bears the heading: 'Pésame que da el Rey de España al nueuo Rey de Inglaterra por la muerte de su padre'. See A.G.S., Estado 8341, Vol. 275, fol. 157r. 
Watteville, Spanish ambassador in London, dated 20 December 1660 and addressed to the Spanish prime minister, D. Luis Méndez de Haro y Guzmán. The baron had informed Haro that the Duke of York was less than pleased with a letter from the Spanish king in which the latter expressed his condolences on the occasion of the death of James' sister, the Princess of Orange. Specifically, James had complained that Philip normally wrote to him in French and signed 'Philip'. This last letter had been in Spanish and Philip had signed 'Yo el rey'. In his note, D. Gregorio confirmed that James' report was accurate. However, he rejected the explanation given to the duke by the baron, namely that the offending letter must have been drafted by a careless secretary. His explanation was as follows:

Hauiendose escrito todas las antecedentes en frances han ido conforme al estilo de aquella lengua, y como esta postrera fue en la castellana no se pudo seguir aquel, sino el que corresponde, y VMg. ${ }^{\mathrm{d}}$ [Vuestra Majestad] ha vsado siempre en esta lengua, en que caue tratamiento de mas prerrogativa, pues le dio VMg. ${ }^{d}$ el titulo de Ser. ${ }^{\text {mo }}$ [Serenísimo] Señor, y Alteza sola, que es lo que se practica con todos los Señores Archiduques de la Casa de Austria, y con el Duque de Anjou, en cuyas cartas, y en quantas VMg. ${ }^{\mathrm{d}}$ escriue al s. ${ }^{\mathrm{r}}$ [señor] emperador al rey de Francia, y a otros que van en lengua española firma VMg. ${ }^{\mathrm{d}}$ : yo el Rey, con que parece que la queja del Duque se ocasiona de estar sin esta noticia. ${ }^{10}$

D. Gregorio went on to conclude his note by reaffirming that 'la diferencia no està en la substancia, y firma de las cartas, sino en lo que caue en la lengua que se escriue, y formalidad que según ella tiene VMg. ${ }^{\text {'’ }}$. His solution was therefore to provide the king with two letters, one in French and the other in Spanish. The king might send both letters to the baron so that the latter, having been enlightened, could forward to the duke the one deemed more appropriate. Alternatively, the king might send whichever of the two letters he preferred. There is no doubt from this episode that the Duke of York was not alone in being ignorant of how epistolary custom and practice in Madrid varied according to the language in which communications were framed. Despite his Burgundian origins and considerable diplomatic experience abroad, the Spanish ambassador in London was equally ignorant. Haro appears to have had nothing to say in this particular instance.

Around the time that he lodged his complaint with the Baron de Watteville, James had a similar set of exchanges with Francesco Giavarina, the Venetian ambassador to London. On 27 August 1660, the ambassador reported that the Dukes of York and Gloucester were dissatisfied with the

10 D. Gregorio de Tapia to Philip IV, Madrid, 2 February 1661, A.G.S., Estado 8341, Vol. 278, fols 264r-265r. 
titles they had been given in recent letters from the Venetian senate. ${ }^{11}$ The irritation of the dukes was manifest in their replies: both had written in French and used titles unsuitable for the republic. However, when questioned by Giavarina, the dukes' secretaries had explained that it had been many years since the King of England had had brothers and the dukes were therefore unsure of how to address foreign potentates. While in exile, they had written to everyone in French, using the titles employed by the Dukes of Orleans and Anjou and saw no reason to discontinue this practice. However, by late October York's attitude had softened. He agreed not to claim the title 'Royal Highness' so long as the republic did not extend it to the brother of the French king. ${ }^{12}$ On 19 November, Giavarina was able to inform the senate that further progress had been made: York had not only withdrawn his request to be addressed as 'Royal Highness' on the grounds that neither the brother of the King of France or of the emperor received this title but he had also modified his position with regard to the way in which he should address the republic. Although his initial preference had been to write to France in order to ascertain what Anjou did, he had now agreed not to seek examples elsewhere but follow the practice of his brother, the king. This entailed using the title 'Most Serene' (Serenissima) and drafting his letters to the republic in Latin. ${ }^{13}$

Cardinal Jules Mazarin: during late 1658 and early 1659, Mazarin spent several months negotiating a cessation of hostilities between Spain and France, as well as what has come to be known as the Paris treaty, with the Spanish envoy, D. Antonio Pimentel de Prado. The purpose of this treaty was to lay the foundation for subsequent talks between Mazarin and Haro scheduled to be held in the Pyrenees during the second half of the year. As he anticipated his talks with Haro, Mazarin became exercised by the Spanish perception of the relative positioning of Spanish grandees and cardinals of the church within the social hierarchy. On 27 March 1659, he wrote to Pimentel requesting precise information on this matter. In a letter to Haro dated the following day, Pimentel detailed his response to Mazarin's query:

Yo le respondi en los terminos que pedia la matheria concluiendo con que no sauia por hauer estado poco en España lo que se estilaua en lo que Su Eminencia deseaua saber pero que en Roma me parecia hauer

11 Francesco Giavarina to Doge and Senate, London, 27 August 1660. See Calendar of State Papers and Manuscripts relating to English Affairs, existing in the Archives and Collections of Venice and in other Libraries of Northern Italy, ed. Allen B. Hinds et al., 41 vols (London: H.M.'s Stationery Office, 1931), XXXII, Entry 204. Venice had used the title 'Highness' without the 'Royal' believed by the dukes to be due to the king's brothers.

12 Francesco Giavarina to Doge and Senate, London, 29 October 1660, ibid., Entry 227. The Duke of Gloucester died at Whitehall Palace on 13 September 1660 . This is why Giavarina's letters of 29 October and 19 November mention only negotiations with York.

13 Francesco Giavarina to Doge and Senate, London, 19 November 1660, ibid., Entry 236. 
oydo (como Su Eminencia decia) no estaua muy asentado el hazer los grandes señores en España tanto con los cardenales como se hacia en otras partes pero que no lo sauia con certeça ni con noticia de la diferencia que se hazia; estaua cierto que VE [Vuestra Excelencia] corresponderia a todo lo que el $\mathrm{s}^{\mathrm{r}}$ cardenal manifestara de Gentileza y Cortesía y que no faltaria en VE el deseo de hazer quanto estubiese en su mano. ${ }^{14}$

This very sensitive matter was not easily resolved. In fact, it was still being debated in August when Haro and Mazarin were finally ensconced in their respective lodgings on either side of the Pyrenean border. According to the Spanish prime minister, the difficulty lay in the fact that neither of the two was free to act unilaterally. Whereas he was obligated to defend the rights of the grandees, Mazarin was bound to safeguard the privileges of the College of Cardinals. The two positions seemed irreconcilable. Nevertheless, an acceptable solution was eventually found. Negotiations would take place in a conference centre constructed jointly by both crowns on a small island that divided the waters of the river Bidasoa close to Fuenterrabía and Hendaye and that, for the purposes of the peace conference, was to be considered neutral territory. This would allow both negotiators to enter the conference room, half of which was deemed to be in Spain and half in France, without ever having to set foot on foreign soil. By this means, the tricky points of honour that would arise over precedence in doorways and permissions to sit to one's right or left were also avoided. More importantly for the subject under discussion, both prime ministers further agreed to dispense with all their titles and use only that of 'plenipotentiary' of their respective royal masters. ${ }^{15}$ This solution makes clear that Haro's encounter with Mazarin involved more than just the reputation of grandees and cardinals of the church. The reputations of the Spanish and French monarchs were also at stake.

D. Luis Méndez de Haro y Guzmán: while he waited in San Sebastian for the peace conference to begin, Haro received a dispatch from Madrid containing powers authorizing him to negotiate with Mazarin. His review of the wording of the powers relating to the projected marriage of Louis XIV and María Teresa of Austria left him dissatisfied and he immediately composed a letter to Madrid outlining his reservations. In particular, he felt it was inappropriate to refer to Mazarin simply as 'el Cardenal Julio Mazarini' and recommended instead insertion of the phrase 'Muy reuerendo padre en Christo el Cardenal Julio Mazarini'. He also proposed that he himself should be addressed as 'Nro [nuestro] muy caro y

14 D. Antonio Pimentel to Haro, Paris, 28 March 1659, A.G.S., Estado Francia K1616: 35 .

15 D. Luis Méndez de Haro y Guzmán, Letters from the Pyrenees: Don Luis Méndez de Haro's Correspondence to Philip IV of Spain, July to November 1659, ed. Lynn Williams (Exeter: Univ. of Exeter Press, 2000), xv, 15-19. 
bien amado Primo' following the precedent of the powers granted in 1612 to the Duke of Lerma, who was to stand in for Louis XIII in his marriage to Anne of Austria, and to the Duke of Guise, who was to represent the young Prince Philip in his marriage to Isabella of France. ${ }^{16}$ In his reply, the king's secretary, D. Fernando de Fonseca Ruiz de Contreras, explained that the powers had been worded very carefully. Mazarin's name appeared without titles in those parts of the document where Haro was referred to by his own name. Elsewhere full titles had been used. With regard to Haro's request to be addressed as Nro muy caro y bien amado Primo', Contreras pointed out that this form of address had not been given because the original power had been drafted in an impersonal style with Haro being referred to in the third person. However, he now enclosed two slightly different sets of powers so that, having had sight of those that Mazarin brought to the conference, Haro might choose which to use. In the one version, Mazarin was referred to simply as 'Muy $\mathrm{R}^{\mathrm{do}}$ [reverendo] en christo Padre'; in the other, Philip had added 'mi muy charo y muy amado amigo', according to the manner in which he normally addressed cardinals of the church when he wrote to them. ${ }^{17}$ Haro was also referred to directly and given the title 'primo'. 18

16 Letters from the Pyrenees, ed. Williams, 14-15. The phrase 'Nro muy caro y bien amado Primo' is the literal equivalent of 'nostre tres-cher \& tres-amé Cousin' that often appears in French powers issued during the same period.

17 D. Fernando de Fonseca Ruiz de Contreras to Haro, Madrid, 3 August 1659, A.G.S., Estado Francia K1623: 36; Philip IV to Haro, Madrid, 3 August 1659, A.G.S., K1622:136. Haro's objections to the wording of the powers had been discussed by the Council of State on 2 August. See Report of the Council of State, Madrid, 2 August 1659, A.G.S., Estado Francia K1618: 18 .

18 When instructed by Louis XIV to publish the treaties struck between France and other potentates over the previous three hundred years, Frederic Leonard, the king's first printer, accompanied the document governing the union of Louis and Maria Teresa with copies of the powers granted to Mazarin and Haro for the purpose of negotiating the marriage contract. Interestingly, Mazarin's powers are those of 21 June 1659 in which he is addressed by Louis in the second person and as 'cousin'. Haro's powers, on the other hand, are those of 5 July in which he is referred to by Philip in the third person and not given the title 'primo'. See Frederic Leonard, Recueil des Traittez de Paix, de Treve, de Neutralite, de Confederation, d'Alliance, et de Commerce, faits par les Rois de France avec tous les Princes et Potentats de l'Europe, et autres, depuis pres de trois siecles, 6 vols (Paris: Chez Frederic Leonard, 1693), IV. The same versions of both sets of powers are to be found in Jacques Bernard, Recueil des traitez de paix etc., 4 vols (Amsterdam: Chez Henry et la Veuve de T. Boom, 1700), III, and, in both Spanish and French, in José Antonio de Abreu y Bertodano, Colección de los tratados de paz etc. (Madrid: Viuda de Diego Peralta, 1740-52). The revised powers forwarded to Haro by Contreras in which the former is referred to as 'primo' seem to have disappeared, although, given the nature of Mazarin's powers, it is hard to believe that Haro would not have used them. However, in the powers granted to Haro by Louis XIV for the purpose of representing him in his marriage to María Teresa by procuration, Haro is addressed as 'primo'. The Spanish translation of the text reads: 'Luis, por la gracia de Dios, Rey de Francia, y de Navarra. A nuestro muy charo, y bien amado Primo Don Luis Mendez de Haro, y Guzman, [...] Salud.' See 'Letras de Comission, y Poder, dadas por el Señor Rey Christianissimo Luis XIV al Conde-Duque de Olivares, para celebrar en Su Real nombre el 
Ferdinand II, Grand Duke of Tuscany: because of difficulties associated with the ranking of allies in the peace treaty of 1659 , Haro and Mazarin had given limited acceptance to a suggestion by the Count of Brienne, Secretary of State for France, that a general clause should be inserted in the treaty stating that 'seran tenidos por Aliados de cada corona aquellos que presentaren despacho (issued by Philip or Louis), declarandolos por tales'. ${ }^{19}$ Notwithstanding the ingenuity of this solution, minor problems remained. On 8 April 1660, the Council of State considered a request from the Grand Duke of Tuscany that, in accordance with articles 122 and 123 of the treaty, he be granted a warrant naming him as an ally of Spain. The request was conveyed by the Grand Duke's ambassador in Madrid, Ludovico Incontri, and accompanied by the original declaration issued by the King of France on 9 November 1659. Having noted that the Grand Duke had requested a warrant from Spain in Fuenterrabía before that date, the council recommended that his request be granted. The warrant was eventually signed by the king and Secretary of State Pedro Coloma on 23 April 1660 as they paused in Burgos on their way to the border in order to deliver the Infanta María Teresa to her prospective husband, the French king. ${ }^{20}$ But this was not the end of the matter. On 8 May, the Council of State was asked to review a formal complaint lodged by the Grand Duke's ambassador in Madrid. According to the ambassador, the warrant issued on 23 April contained no fewer than four errors: (1) Ferdinand had not been given the title 'Gran Duque de Toscana'; (2) he had not been addressed as 'Señor Hermano' (as he was customarily addressed by Philip) or as 'Primo' (a form of address to which he was entitled by blood); (3) he had not been referred to as 'El Señor Gran Duque' (as in the warrant issued by the French king); (4) the warrant had been dated as of the day it had been signed by Philip and not backdated, as promised by Haro, so as to indicate that the Grand Duke had been the first to receive such a document from Spain. The Council of State quickly agreed to recommend that the first and last of these points might be conceded. ${ }^{21}$ However, it felt unable to recommend acceptance of the second since what

Desposorio con la Serenissima Señora Infanta Doña Maria Teresa de Austria, Hija primogenita del Señor Rey Catholico D. Phelipe IV: dadas en Tolosa a 10 de Noviembre de 1659', in Abreu y Bertodano, Colección de los tratados de paz etc., microfilm 05234, reel 5, Princeton Univ. Library, Princeton, p. 364.

19 Letters from the Pyrenees, 44. This clause did not cover major allies like the pope and the emperor. Louis' allies are listed in article 122 and Philip's in article 123 of the treaty.

20 Report of the Council of State, Madrid, 8 April 1660, A.G.S., Estados pequeños de Italia 3680: 33; Warrant granted to Grand Duke of Tuscany by Philip IV, Burgos, 23 April 1660, A.G.S., Estados pequeños de Italia 3680: 37.

21 Report of the Council of State, Madrid, 8 May 1660, A.G.S., Estados pequeños de Italia 3680: 41 . The Grand Duke's desire to be the first ally to receive a warrant from Spain relates specifically to longstanding rivalry between the Grand Duchy and the Republic of Genoa in matters of precedence. 
Ferdinand sought was inconsistent with the nature of the warrant granted. What was appropriate in a personal letter was inappropriate in a public declaration. The Council also felt unable to recommend acceptance of the third point on the ground that the French declaration had been drafted by the king's secretary and the king referred to in the third person. The warrant issued by Spain was very different in that the first person style used in it referred to the Spanish king. Accordingly, the Council argued that the French document 'mas parece una certificacion particular, que vn despacho formal del Rey' and supplied Philip with a literal translation of the French for his inspection. ${ }^{22}$ In a note scribbled in the margin of the Council's report, Philip accepted the recommendations put to him but noted that acceding to requests of precedence would only create the very problem that Haro had sought to avoid by not naming allies in the treaty. ${ }^{23}$ The Count of Brienne's ingenious solution had merely shifted the thorny questions of precedence and appropriate forms of address from one arena to another.

Republic of Genoa: by 1659, relations between Genoa and Madrid were strained by the inability of the two powers to agree on a suitable form of address for the republic. While Mazarin and Haro were conducting their negotiations in the Pyrenees, Genoa repeated to Madrid its request that ministers of the Spanish crown should address the republic as 'Serenidad'. In a meeting convened on 15 October 1659, the Council of State saw no reason to alter custom and practice and advised the king accordingly. ${ }^{24}$ Later in the year, Genoa wrote to Philip in order to congratulate him on having agreed peace with France and arranged the marriage of his daughter, María Teresa, to the French king. This communication, which was drafted in Italian, may have been intended as a deliberate snub to Philip because of his recent refusal to allow his ministers to address the republic as 'Serenidad'. When considered by the Council of State on 22 February 1660, it was certainly deemed to be unacceptable. In its report to Philip, the Council declared: 'Al Consejo Pareçe que esta Carta no biene muy reberente, y que por eso podria VMag. ${ }^{d}$ seruirse de mandar que se responda con sequedad.'25

22 Report of the Council of State, Madrid, 8 May 1660, A.G.S., Estados pequeños de Italia 3680: 41. It appears from this that Philip did not know French. In fact, there is reason to suppose that he knew only Spanish. This, at least, is what two Genoese envoys claim in 1622 in a report prepared for the Republic of Genoa. See Fernando Diaz-Plaja, Historia de España en sus documentos: siglo XVII (Madrid: Cátedra, 1987), 100.

23 Report of the Council of State, Madrid, 8 May 1660, A.G.S., Estados pequeños de Italia 3680: 41 .

24 Report of the Council of State, Madrid, 15 October 1659, A.G.S., Estado Génova 3609: 124. The form of address normally given to Genoa at this time was 'Señoría'. See Avisos de Don Jerónimo de Barrionuevo, 1654-1658, ed. A. Paz y Meliá (Madrid: Ediciones Atlas, 1968), 268.

25 Republic of Genoa to Philip IV, Genoa, 19 December 1659, A.G.S., Estado Génova 3609: 140; Report of the Council of State, Madrid, 22 February 1660, ibid., 139. 
Duke of Orleans: the importance of observing epistolary etiquette is further illustrated in an exchange between the Duke of Orleans and Philip IV in 1651 . The duke had written to Philip in French with a request that the Duke of Guise, who was at the time a prisoner in Spain, be swapped for a number of Spanish prisoners held in France. In its meeting of 7 August, the deliberations of the Council of State focused, significantly, not on the duke's request but on his lack of attention to protocol. The Council particularly objected to the fact that the duke had addressed Philip as 'Monsieur' and recommended that the king should respond appropriately. ${ }^{26}$ This is the background to the order issued later in the month outlining how Philip's reply to the duke should be framed. According to this order, the letter should be drafted 'en español con dos dedos de margen'. Also 'el sobreescrito cerrando la carta con nema ha de decir: Al Serenísimo señor Gaston de Bourbon, Duque de Orleans mi hermano'. ${ }^{27}$ If we compare the protocol used here with that used in a letter written by Philip to the duke in 1642, we immediately see the difference. The instructions issued in 1642 were as follows:

Hase de escribir en frances.

$\mathrm{Al}$ principio del primer renglon: Monsieur Mon bon frere.

El tratamiento de Alteza.

$\mathrm{Al}$ fin de la carta: a tant Mon bon frere se prie Dieu conserver VA en parfaite santè a longues annees.

Sobre la firma: Vré [vôtre] bon frere

Sobrescrito: A Monsieur mon bon frere le Duqc [sic] de Orleans ${ }^{28}$

It seems likely that Philip's letter of 1651 was drafted so as to indicate royal displeasure with the lack of etiquette displayed by the duke.

States General of the United Provinces of the Low Countries: we have looked at a number of instances of the use of 'hermano', 'primo' and their French equivalents in royal communications of various kinds. As indicated above, other titles were also used, especially when addressing republics. We find one example in the letter that Philip wrote to the States General of the United Provinces in order to introduce his new ambassador, D. Esteban de Gamarra y Contreras. The letter, which is in French, is an excellent translation of a Spanish original and was drafted according to very specific instructions: (1) the States General were to be addressed as 'Tres chers et grands amis'; (2) at the end of the letter were to appear the

26 Report of the Council of State, Madrid, 7 August 1651, A.G.S., Estado Francia K1420: 141. In French, Philip could expect to be addressed at the start of a letter as 'Sire' rather than 'Monsieur'; in Spanish, he would be addressed as 'Señor'.

27 Philip IV to the Duke of Orleans: reply to the Duke's proposal to exchange the Duke of Guise for Spanish prisoners in France, Madrid, August 1651, A.G.S., Estado Francia 1420: 140. 74 .

28 Philip IV to Duke of Orleans, Madrid, 13 March 1642, A.G.S., Estado Francia 1420: 
words 'surquoy nos prions Dieu qu'il vous ayt tres chers et grands amis en sa saincte garde'; (3) the signature should read 'Vré bien bon Ami Philippe'; (4) on the envelope should be written 'a nos tres chers et grands amis les etats Generaux des Prouinces Vnies du Pais Bas'. ${ }^{29}$ Like all powers of the time, the United Provinces had a clear sense of where they ought to figure within the European diplomatic hierarchy. For example, when, in April 1660 , they were preparing to send three ambassadors extraordinary to Madrid in order to congratulate Philip on having made peace with France and assure him that they would honour the peace and maritime treaties they had signed with Spain in Münster and The Hague, they instructed their ambassadors to keep 'la presedencia immediatam te despues de los embax. $^{\text {res }}$ [embajadores] de los Reyes, y de la Rep.ca [República] de Venecia'. ${ }^{30}$ This suggests that they saw themselves as more important than Genoa and even England, which, at the time the ambassadors' instructions were being prepared, was still a republic. Given this sense of importance, the States General would naturally expect to be addressed appropriately by the Spanish monarch. The appropriate form of address in their case was 'tres chers et grands amis'.

\section{The Courtly World of Philip IV}

In his dealings with the Spanish nobility, Philip seems to have been a strict observer of protocol. While grandees like Haro, as we have seen, had the privilege, in formal communications, of being addressed as 'primo', the noble of lesser status who nevertheless enjoyed the king's favour might expect to be referred to as 'pariente'. An example of this is found in an official dispatch drafted in December 1644 in which Philip informs the Count of Fuensaldaña of a change in the government of Flanders. The

29 Philip IV to the States General of the United Provinces of the Low Countries, Madrid, 27 July 1658, A.G.S., Estado Francia K1686: 49a. Document 49b is the original letter in Spanish while document $49 \mathrm{c}$ contains the instructions listed above for the drafting of the letter in French. It is worth noting that Philip usually wrote to his officials in Brussels in French. His use of French in letters to the States General may therefore be no more than a continuation of what was custom and practice before the United Provinces broke away from the rest of Flanders and Spain.

30 Translation of the Instructions given by the States General to their Ambassadors Extraordinary to Spain. To be dispatched to the Most Excellent D. Luis Méndez de Haro on 30 June 1660, Estado Flandes 2097. The instructions were translated in the United Provinces by Gamarra or, more probably, by one of his staff and were forwarded to Madrid in the spring of 1660 . In connection with this particular embassy, it may be noted that Madrid itself was unsure of how to address the three ambassadors because, according to the Council of State, they were los primeros que en este grado han venido dellos a VM.' Consequently, the Count of Fuensaldaña, Spanish ambassador extraordinary to Paris, was instructed to ascertain how they were addressed by the French court, which they were to visit prior to continuing their journey to Madrid. See Report of the Council of State, Madrid, 7 July 1660, A.G.S., Estado Flandes 2097. 
relevant part of this dispatch reads as follows:

El Rey: Conde de Fuensaldaña pariente, mi Castellano Gobernador y Capitán General del país de Cabresis [sic]: a D. Juan de Austria mi hijo he nombrado por Gobernador y Capitán General de esos Estados [... $]^{31}$

A similar distinction between those who were grandees and those who were not was maintained by the nobles themselves. For instance, the king's personal secretary, Contreras, acknowledges Haro's status as grandee and first minister of the crown by addressing him as 'Vuestra Excelencia'. Haro, on the other hand, invariably reciprocates with 'Vuestra Señoría', the form of address to which titled gentlemen and Contreras, as Marquis of La Lapilla, had just claim. ${ }^{32}$ In contrast, untitled functionaries seem to have been bundled together with no regard for any difference in the importance of the position they might hold. When addressing such individuals, palace protocol demanded use of 'Vuestra Merced', as the following exchange between Pedro Coloma, one of Philip's secretaries of state, and Juan Botín, an official in the bureau of translation, makes absolutely clear:

\section{(a) Coloma to Botín}

Los diputados del condado de Borgoña escriben a su $\mathrm{Mg}^{\mathrm{d}}$ [Majestad] la carta que va aquí. VM [Vuestra Merced] se sirua de mandarla traducir y voluermela para que se pueda veer en el conss. ${ }^{\circ}$ [consejo] y dar quenta a su $\mathrm{Mg}^{\mathrm{d}}$ de lo que en ella se refiere. Dios $\mathrm{g}^{\text {de }}$ [guarde] a VM como desseo. Caragoza [sic] 9 de set ${ }^{\mathrm{e}}$ [setiembre] 1646. Pedro Coloma ${ }^{33}$

(b) Botín to Coloma

$\mathrm{S}^{\mathrm{r}}$ [Señor]: Esta carta vuelue traduçida, pero no pareçe es para su $\mathrm{M}^{\mathrm{d}}$ [Majestad] (como VM lo mandara ver por ella) sino para el $\mathrm{S}^{\mathrm{r}} \mathrm{Marq}^{\mathrm{s}}$ [Marqués] de Castel $\mathrm{R}^{\circ}$ [Rodrigo], o, otro ministro de cuya intercesión

31 Díaz-Plaja, Historia de España en sus documentos, 216. For another example, see also Philip IV to Marquis of Caracena, Madrid, 17 October 1659, A.G.S., Estado Francia K1622: 201.

32 See, for example, Contreras to Haro, Madrid, 31 October 1659, A.G.S., Estado Francia K1621: 52; and Haro to Contreras, Fuenterrabía, 17 August 1659, A.G.S., Estado Francia K1623: 46. Untitled individuals also observed this distinction, using 'Vuestra Excelencia' to address nobles who were grandees and 'Vuestra Señoría' to address those who were not. To use the wrong form of address was to give serious offence. In 1635, the Duke of Braganza disregarded a summons from the Duchess of Mantua, Governor of Portugal, to attend the palace in Lisbon. The reason for the duke's disobedience was that the servant conveying the summons had addressed him as 'Señoría', not 'Excelencia'. See Diaz-Plaja, Historia de España en sus documentos, 156.

33 Pedro Coloma to Juan Botín, Saragossa, 9 September 1646, A.G.S., Estado Flandes 2066. In 1645-46, several years into the long Catalan revolt, Philip spent time in Aragon and Valencia. Naturally, the Council of State, together with a host of functionaries like Botín, travelled with him. 
con su $\mathrm{M}^{\mathrm{d}}$ se vale la Borgoña $\mathrm{p}^{\mathrm{a}}$ [para] su pretensión. Dios gde a VM muchos años como sus seruidores desseamos.

Del escrit ${ }^{\circ}$ [escritorio] 11 de settre 1646 . Juan Botín ${ }^{34}$

Despite reciprocal use of 'Vuestra Merced' by Botín and Coloma, Botín is nevertheless able to signal his subordination to the latter by addressing him as 'señor' at the start of his note and also by choosing an appropriate formulaic closure, namely 'como sus seruidores desseamos'.

The second person singular pronoun 'tú' does not figure in any of the many hundreds of documents relating to the diplomatic and courtly worlds of Philip IV that I have been able to consult. Its complete absence in these contexts accords better with the explanation of its use recorded in Covarrubias' Tesoro than with that offered in Autoridades (see appendix). 'Vos', on the other hand, occurs frequently, although it is mostly used by the king, who employs it to address noble and non noble alike. For example, he uses it in communications to his illegitimate son, D. Juan [José] de Austria, and also to Jacques Brecht, secretary to the Council of Flanders in Madrid, whom he charges in 1640 with a delicate diplomatic mission to France. ${ }^{35}$

When nobles and non nobles address the king, they use 'Señor' and 'Vuestra Majestad'. Lerma, Olivares and Haro, 'validos' of Philip III and Philip IV and representatives of the first group, show themselves to be remarkably consistent in using only these forms of address. ${ }^{36}$ D. Gregorio de Tapia, as we have seen in the section devoted to the Duke of York, behaves in like manner and may be considered representative of the second group. $^{37}$ Naturally, 'Vuestra Majestad' takes the third person singular form of the verb and, when replaced, is replaced by a third person singular object pronoun, as the following extracts from two of Haro's letters to Philip IV confirm:

(a) Acabo de reçiuir el despacho de $\mathrm{VM}^{\mathrm{d}}$ de 27 del pasado en respuesta del mio de los 22 del mismo y por no detener este correo con deseo de que a $\mathrm{VM}^{\mathrm{d}}$ no le falten frecuentes nueuas de aquí, remito el satisfaçer a los puntos que contiene con el primero.

34 Juan Botín to Pedro Coloma, 11 September 1646, A.G.S., Estado Flandes 2066.

35 Philip IV to D. Juan de Austria, Madrid, 16 October 1658, A.G.S., Estado Francia K1686: 98; Philip IV to Secretary Jacques Brecht, Madrid, 19 April 1640, A.G.S., Estado Francia K1420:51. While Philip most often uses 'vos' to address Spanish nobles, he does also use other forms. When Pimentel is negotiating a truce with Mazarin in Paris in 1659, Philip addresses him as 'Vuestra Señoría'. See Philip IV to D. Antonio Pimentel, Madrid, 10 June 1659, A.G.S., Estado Francia K1616: 58.

36 Díaz-Plaja, Historia de España en sus documentos, 91-92; Letters from the Pyrenees, passim.

37 See footnote 10. 
(b) En carta de primero deste se sirue VMgd de mandarme decir sobre las materias de Inglaterra las palabras siguientes $[\ldots]^{38}$

However, there are exceptions to this practice. For instance, when in 1629 Quevedo reports to Philip on the situation in Italy, he uses not just 'Señor' and 'Vuestra Majestad', but also 'vos'. We thus find in a single document a rich mixture of pronominal and verbal usage in connection with the king:

(a) Ayer no quería (the French king) que el duque de Mantua fuese duque de Mantua, sólo porque estaba debajo de vuestra protección; y hoy quiere que lo sea porque está en la suya fuera de la vuestra.

(b) Y debe advertir vuestra majestad que el duque de Saboya [...] ha de preferir siempre la amistad con Francia a la que con vuestra majestad tuviere; que así lo manda la naturaleza de su estado y el sitio de él; pues contra vos, de Francia puede ser socorrido, contigua y continuamente, y de vos contra Francia no con esta prontitud y facilidad.

(c) Grande parte de las victorias que os dieron aquellos estados debe vuestra majestad a la casa de Oria (Doria), y su patria la libertad; y en estos servicios debéis emulación muy esclarecida en Flandes a la casa de Espínola.

(d) No trato en si a vuestra majestad le es a propósito hacer paces con el Turco $[\ldots]^{39}$

Unlike Quevedo, Haro, as we have noted, is careful not to mix forms of address in his correspondence to the king. However, he does sometimes mix them when writing to others. Although he normally addresses Pimentel as 'Vuestra Señoría', he also uses 'vos'.40 In the same way, Condé alternates 'Vuestra Excelencia' and 'vos' when writing to Haro, just as Haro alternates forms when writing to him. ${ }^{41}$ The close semantic and formal connections between the subject pronoun 'vos' and the possessive 'vuestra' in constructions like 'Vuestra Majestad', 'Vuestra Alteza', 'Vuestra Excelencia' and 'Vuestra Señoría' probably facilitate the switch from one form of address to the other. The fact that the same kind of switch is not

38 Letters from the Pyrenees, 18, 22.

39 Díaz-Plaja, Historia de España en sus documentos, 124-26, 207-08.

40 Ibid., 274; Haro to Pimentel, Madrid, 17 March 1659, A.G.S., Estado Francia K1624: 25b.

41 Condé to Haro, Brussels, 16 July 1659, A.G.S., Estado Francia K1623: 14; Haro to Condé, Fuenterrabía, 16 November 1659, A.G.S., Estado Francia K1623: 144. Louis Bourbon, otherwise known as the Grand Condé, was a French prince of the blood and Philip's principal ally in the 1650 s. Despite his princely status, Condé opens his letter to Haro with 'Señor mio' and closes it with: 'soy con toda verdad $\mathrm{s}^{r}$ mio de VE su muy aficionado seru ${ }^{\text {or }}$ [servidor], Luis de Borbon.' Given the contemporary obsession with getting forms of address right, one may expect the Spanish translation to be an exact equivalent of the original French. 
attested, so far as I know, in the case of 'Vuestra Merced' suggests that in the courtly and diplomatic worlds of Philip IV, 'vos' was invested with a highly positive value. ${ }^{42}$ In other words, complete exclusion of 'tú' from these contexts, together with the reservation of 'vos' for occasions when one addressed an individual 'de gran Dignidad', ${ }^{43}$ implies that 'Vuestra Merced' occupied the very bottom tier in a complex, but highly stratified world. Such an interpretation of the values of 'vos' and 'Vuestra Merced', it has to be said, stands in stark contradiction to statements of a general nature regarding these forms of address by some of the most authoritative figures in the field. ${ }^{44}$

42 On the one hand, it is worth remembering that Philip uses 'vos' to address non nobles and also men of the cloth. For an example of the latter, see Philip to the bishop of Bois le Duc, Madrid, 19 April 1640, A.G.S., Estado Francia K1420: 52. On the other hand, it is worth noting that in her capacity as governor of Portugal, the Duchess of Mantua offended the 'oídores' when calling her first meeting of the council of state, because she addressed them as 'vos'. If by 'oídores' is meant 'letrados' and 'magistrados', this episode lends some support to the interpretation of 'vos' and 'Vuestra Merced' I advance here. The correct form of address in the case of these functionaries would probably have been 'Vuestra Merced'. See Díaz-Plaja, Historia de España en sus documentos, 156.

43 Autoridades, s.v. vos (see appendix).

44 See Real Academia Española, Esbozo de una nueva gramática de la lengua española (Madrid: Espasa-Calpe, 1977), 342, n.15: 'El tratamiento de vuestra merced fue desde el principio más cortés y respetuoso que el vos.'; Rafael Lapesa, Historia de la lengua española, (Madrid: Gredos, 1983), 392: 'La puntillosidad de nuestros antepasados relegó el tú a la intimidad familiar o al trato con inferiores y desvalorizó tanto el vos que, de no haber gran confianza, era descortés emplearlo con quien no fuese inferior'; Ralph Penny, Variation and Change in Spanish (Cambridge: Cambridge U. P., 2000), 152: 'during the fifteenth century, the type Vos sois/sos (<sodes) became gradually less deferential, coming to be used among equals at various social levels and therefore often becoming indistinguishable from Tú eres'. For a serious study that focuses specifically on the closing years of Philip IV's reign and supports this traditional position, see F. W. Hodcroft, '¿A mí un él?: Observations on vos and él/ella as Forms of Address in Peninsular Spanish', Journal of Hispanic Research, II (199394), 1-16. Having examined correspondence between the Duke of Montalto and Philip, as well as between the duke and the queen following Philip's death, Hodcroft concludes that during the Golden Age, vos 'suffered progressive debasement and consequent semantic restriction' (1). In fact Hodcroft places vos almost at the bottom of the Golden-Age hierarchy of tratamientos, although he qualifies it as 'non-elevated' without further explanation (13). My reading of the portions of the correspondence reproduced by Hodcroft leaves the conclusion much more open. As Mayordomo Mayor in charge of the queen's household, Montalto is concerned to discover palace protocol regarding the way in which he should address officials under him. He consults the king and, subsequently, the queen, and is instructed accordingly. However, it seems that these instructions are provisional and perhaps even something of a compromise: the king opens his reply with the words 'En el interin' (3), and the queen orders a reluctant Montalto to accept the 'temperamento' he has been given (6). Hodcroft's use of [sic] after 'temperamento' is, I believe, unwarranted. Furthermore, Montalto has requested guidance that relates specifically to how a Mayordomo Mayor should address his 'súbditos' or household. Two important points arise: (i) the word 'súbdito' suggests rather more than 'subordinate', which is how Hodcroft appears to understand it (see pp. 2, 4,6). It implies a relationship akin to that which exists between a monarch and his subjects and would explain why a Mayordomo Mayor was entitled to use vos when addressing officials under him. Social inferiors who did not belong to the 
Discussion of 'vos' invites consideration of the morphology of the second person plural of the verb. The issue in question has to do with retention and elimination of $-d$ - in the different forms that this person of the verb takes. According to Dworkin, the likely starting point for the elimination of $-d$ - is lower class speech of the fourteenth century, which begins to drop this sound in the present subjunctive of -ar verbs (cantedes), in the present indicative of -er verbs (comedes) and in the future of all conjugations (andaredes etc.). ${ }^{45}$ In other words, - $d$ - disappears first in paroxytonic forms whose stressed vowel is /e/. Blaylock, drawing on the work of Rufino José Cuervo, argues that by the middle of the sixteenth century the language contrasts the present tenses, which eliminate $-d$-, with the other tenses, which retain it. He reports widespread loss of $-d$ - in proparoxytonic forms such as hablárades and hablariades etc. by the second decade of the seventeenth century and wholesale elimination of this consonant in all relevant verb forms by the early eighteenth century. ${ }^{46}$ Penny agrees with Dworkin that elimination of $-d$ - has its origin in paroxytonics in the fourteenth century, and observes that it becomes regular in proparoxytonics during the course of the sixteenth century. ${ }^{47}$

Retention of $-d$ - is relatively rare in the seventeenth-century documents I have examined. There are occasional instances of it in proparoxytonic forms (enviábades) in the writings of Quevedo and others. ${ }^{48}$ However, most instances of retention are to be found in Philip's own correspondence. This should hardly surprise us since it is the king who is by far the main user of the 'vos' form of address. ${ }^{49}$ In Philip's writings, then, we find numerous

household could hardly be described as 'súbditos' and probably should not be addressed as 'vos'. This is why Montalto is so troubled when, following Philip's death, he is asked to direct temporarily the king's household. Specifically, he observes: 'siento dificultad en tratarlos (i.e., members of the king's household) de vos, no hallándome su mayordomo mayor' (4); (ii) as noted, Hodcroft deals with a very particular situation, namely the nature of the relationship between a Mayordomo Mayor and his household. There would appear to be no reason to extend the protocol operating here to all palace contexts. Plainly, this is an area in need of further archival research.

45 Steven N. Dworkin, 'The Diffusion of a Morphological Change: the Reduction of the Old SpanishVerbal Suffixes - ades, -edes and -ides', Medioevo Romanzo, XIII (1988), 223-33.

46 Curtis Blaylock, 'Notes on the Chronology of a Morphophonological Change in Golden-Age Spanish: the Loss of -D- in Proparoxytonic Forms of the Second Person Plural Verbs', HR, LIV (1986), 279-85.

47 Penny, Variation and Change in Spanish, 154. In his A History of the Spanish Language (Cambridge: Cambridge U. P., 1991), 139, he says that - $d$ - begins to be eliminated from proparoxytonics in the sixteenth century, disappearing altogether by the late seventeenth century

48 See, for example, Díaz-Plaja, Historia de España en sus documentos, 207-08.

49 Some caution is needed here. Whilst it is true that brief notes are often penned by the king, the vast majority of letters and other documents bearing his signature are drafted by his secretaries. It is therefore not clear what his level of involvement was. Did he, for example, dictate to a scribe? Did he review drafts and make changes in the manner of Alfonso X? Whatever his role may have been, one thing is nevertheless clear: documents bearing his signature show a higher incidence of forms retaining - $d$ - than any others I have 
instances of the following kinds:

(a) Imperfect indicative: pensauades, teniades, deciades.

(b) Conditional: esperariades, podriades, reçiuiriades.

(c) Imperfect subjunctive: auisasedes, dijiesedes, partiesedes. Forms in -ra (deuierades), whether with a pluperfect or imperfect subjunctive value, are less common.

(d) Future subjunctive: dieredes, tuuieredes. ${ }^{50}$

What emerges from this brief examination of second person plural forms in documents signed by the king is that retention of $-d$ - is common in proparoxytonics belonging to all three conjugations. If we add to the examples listed occasional instances of forms like perseuerades and juzgaredes, which exhibit a paroxytonic stress pattern, the conservative or archaic character of Philip's language is left beyond doubt.

\section{Conclusion}

The courtly and diplomatic worlds of Philip IV are complex worlds and part of their complexity is reflected in an elaborate system of forms of address. Close scrutiny of this system permits us to draw a number of conclusions:

(1) The system is multi-polar and therefore considerably more sophisticated than the bipolar system described by Brown and Gilman in their otherwise excellent study of second person forms of address. The implications of this are obvious. Whether one is dealing with one's social superior or inferior, care must be taken to select the correct form of address since this is a crucial way of signalling the addressee's position within a highly stratified world.

(2) Individuals who are excluded from society naturally lose their place within the social hierarchy and pose an almost intractable problem for those who are required to address them. What, for example, is the status of a king without a kingdom? This is just one of the difficult issues with which Philip's Council of State has to grapple.

(3) Forms of address and epistolary etiquette vary according to the language in which communications are framed. As we see in the Duke of York's protestations to Haro, this is not always properly understood even by those with substantial diplomatic experience like the Spanish ambassador in London.

encountered.

50 See A.G.S. Estado Francia K1622, K1625, K1686. These three 'legajos' contain dozens of documents produced during the period 1658 to 1660 and having the king's signature. 
(4) Style (whether direct or indirect), as well as the status of a document (whether a personal letter, public warrant or whatever) are also relevant factors, as Haro and the Grand Duke of Tuscany discover.

(5) Individuals, monarchies and republics keep an ever watchful eye on how their counterparts elsewhere are addressed and on which forms of address these extend to others. The Dukes of York and Gloucester insist on following the examples of Orleans and Anjou in the way that they address Venice and in the way they require Venice to address them. Similarly obsessed are the court in Madrid (what level of deference will France show to the three Dutch ambassadors extraordinary who are about to visit both courts?), Mazarin, Haro, the Grand Duke of Tuscany, the Republic of Genoa and the States General of the United Provinces of the Low Countries.

(6) Although nobles within Philip's court are accorded different forms of address according to status, untitled functionaries are not. They all seem to receive 'Vuestra Merced' (or 'vos', if addressed by the king) regardless of the function they perform.

(7) In general, palace protocol seems to assign a higher value to 'vos' than to 'Vuestra Merced'.

(8) Philip's language is archaic in at least one sense. He retains a high incidence of retention of $-d$ - in the second person plural of the verb, occasionally preserving the consonant even when the stress pattern is paroxytonic. 


\title{
APPENDIX
}

There follows a list of the forms of address studied in this article, together with explanations of how such forms were to be used in the seventeenth and early eighteenth centuries. The two main sources I have consulted are:

Sebastián de Covarrubias, Tesoro de la lengua castellana o española (1611), ed. Martín de Riquer (Barcelona: S.A. Horta, 1943). Riquer's text contains the additions of Benito Remigio Noydens, which were included in the 1674 edition.

Real Academia Española, Diccionario de Autoridades, 3 vols (Madrid: Editorial Gredos, 1963; repr. 1976).

\begin{abstract}
Alteza
Autoridades: Tratamiento distintivo que se dà à los hijos de los Reyes, Príncipes soberános, y Electores del Imperio: ò con el aditamento de Reál, como se dá à los Duques de Saboya, ù de Electoral à los Electóres, y de Serenissima à los hijos de Reyes y Príncipes soberános.

Tesoro: Título real, después de Majestad; éste se da al Consejo, en quanto representa la persona real, y al Príncipe, como a hijo suyo.

\section{Beatitud}

Autoridades: Tratamiento que se dá al Sumo Pontífice, que es igual al de Santidád, que también se le dá para distintivo y connotádo de su sagrada y elevada Dignidád y Persóna.

Tesoro: Aunque en rigor sinifique la bienaventuranza, es uno de los títulos que damos al Sumo Pontífice, llamándole Beatitud, Beatíssimo padre y Santidad, que dize en abstracto más que beato y santo; aunque también le llamamos Padre santo, que no es menos honorífico y reverencial.
\end{abstract}

\section{Eminencia}

Autoridades: Título y grado honorífico de que oy gozan, y con que son tratados los Cardenáles de la Santa Iglesia Romana, desde el Pontificado de Urbano VIII, que les dió y concedió este honór. Goza este mismo título el Gran Maestre de Malta.

Tesoro: not registered.

\section{Excelencia}

Autoridades: Tratamiento, título y cortesía que se dá al que es Grande de España, y que el dia de oy conforme á estilo se ha extendido á otras persónas, según su grado. Tesoro: not registered.

\section{Excelentísimo}

Autoridades: Tratamiento y cortesía con que se habla à la persona que tiene el grado de Excelencia.

Tesoro: not registered. 


\section{Hermano}

Autoridades: Tratamiento que dán los Reyes á otros Reyes, y á los Cardenales y Obispos.

Tesoro: not registered as a form of address used in diplomatic or courtly circles.

\section{Ilustre}

Autoridades: Significa también título de dignidád: y assi se suele decir, al Ilustre Señor, y suele añadirse el mui, sin equivaler no obstante al tratamiento de Ilustrísima, uso freqüente de algunos Tribunales.

Tesoro: Muy ilustre, ilustrísimo, títulos de diferentes personas y dictados.

\section{Ilustrísima}

Autoridades: Usado como substantivo, significa el tratamiento, que se dá à personas constituidas en dignidád Eclesiastica: como Arzobispos ù Obispos, ò por pragmàtica ù atencion: y tambien à otras personas Seculares, según estilo $\mathrm{y}$ practica. Lat. Illustrissimus. RECOP. lib. 4. tit. I.1.16. Y mandamos, que a ninguna persona, de qualquier estado ò condicion que sea, no siendo de las expresadas en esta nuestra ley, se les pueda llamar ni llame Señoría [...] ni Ilustrísima, sino es à los que se manda ò permite llamar en esta nuestra ley.

Tesoro: no separate entry for this form.

\section{Majestad}

Autoridades: Título honorífico, que propriamente pertenece à Dios, como à verdadera Majestad infinita, y después à sus retratos en la tierra, quales son los Emperadóres y los Reyes: y assi se dice, Vuestra Majestad, su Majestad, \&c.

Tesoro: Latine maiestas, título imperial o real, de a par de emperador.

\section{Merced}

Autoridades: Tratamiento o título de cortesía, que se usa con aquellos que no tienen título ù grado por donde les toque la Señoría.

Tesoro: Merced es una cortesía usada particularmente en España, como en Italia la Señoría, que es común a cualquier hombre honrado, y entonces se dize derechamente de la palabra meritum, que por ser persona que merece* ser honrado la llamamos merced.

\section{Pariente}

Autoridades: En estilo familiár y cortesano se llaman el marido y la mugér. Tesoro: not registered as a form of address.

\section{Primos}

Autoridades: En estilo familiar llaman à los Grandes de España, por ser el título con que los trata el Rey. Lat. Primates Hispanici.

Tesoro: not registered as a form of address in diplomatic and courtly circles.

\section{Señor}

Autoridades: 1. Por antonomasia absolutamente se entiende de Dios, como dueño, que es, de todas las cosas criadas, Rey de Reyes, y Señor de los Señores; pues lo mismo es decir el Señor, que entenderse Dios. 2. Vale tambien el que possee 
Estados, y lugares con dominio, y jurisdicción en ellos. Por antonomasia se entiende de los Reyes, Principes, y Grandes del Reino. 3. Se usa tambien por término de cortesía, hablando con alguno, aunque sea igual, ò inferior.

Tesoro: Este nombre de señor, absolutamente pertenece a sólo Dios, y assí algunos monarcas, aunque gentiles, le renunciaron, y no le quisieron admitir por no ser suyo, como lo hizo Augusto César, que por edicto público mandó que no le llamassen señor.

\section{Señoría}

Autoridades: 1. Tratamiento, que se dá a las personas constituidas en dignidad, à quienes les compete por ella. 2. Se usa tambien por el Senado, que gobierna algun Estado particular.

Tesoro: Es la cortesía que se da a los señores titulados.

\section{Serenidad}

Autoridades: Título de honór que se dá à los Soberanos.

Tesoro: not registered in this sense.

\section{Serenisimo}

Autoridades: Se usa tambien como título de honór, que se dá en el tratamiento à los Principes, hijos de Reyes, y à las Repúblicas.

Tesoro: Es un gran título, más que excelentíssimo, devido a los príncipes; contiene en sí una grandeza de ánimo y una igualdad en todos los sucesos que ninguno le altera ni le haze mudar el semblante; $y$ en esto se muestra el gran valor y pecho de un príncipe y de un rey.

\section{Tú}

Autoridades: Se usa asimismo en el trato comun, hablando con familiaridad, ò amistad, ò con superioridad al inferior.

Tesoro: Pronombre primitivo de la segunda persona, no se dize sino a criados humildes y a personas baxas, en nuestra lengua castellana hablando ordinariamente; pero acomodándonos con el uso de la lengua latina dezimos tú al mismo Dios y Señor nuestro, diziendo: Tú, señor, ave piedad de mí etc.

\section{Vos}

Autoridades: 1. Pronombre, lo mismo que Vosotros. Lat. Vos. 2. Se usa tambien hablando con personas de gran Dignidad, como tratamiento de respeto. 3. Se usa assimismo como tratamiento que dán los superiores à los inferiores.

Tesoro: Pronombre primitivo, de la segunda persona del plural, aunque usamos dél en singular, y no todas vezes es bien recebido, con ser en latín término honesto y común a todos. 